Article

\title{
The Bidirectional Causality between Country-Level Governance, Economic Growth and Sustainable Development: A Cross-Country Data Analysis
}

\author{
Cristina Boţa-Avram ${ }^{1, *(\mathbb{1})}$, Adrian Groşanu ${ }^{1}$, Paula-Ramona Răchişan ${ }^{2}$ and \\ Marius Dan Gavriletea 2 (D) \\ 1 Faculty of Economics and Business Administration, Babeş-Bolyai University, 400084 Cluj-Napoca, Romania; \\ adrian.grosanu@gmail.com \\ 2 Faculty of Business, Babeş-Bolyai University, 400084 Cluj-Napoca, Romania; \\ rachisan_ramona@yahoo.com (P.-R.R.); dan.gavriletea@tbs.ubbcluj.ro (M.D.G.) \\ * Correspondence: botaavram@gmail.com; Tel.: +40-740-048-084
}

Received: 15 January 2018; Accepted: 10 February 2018; Published: 13 February 2018

\begin{abstract}
In the context of contemporary society, characterized by the information users' growing and differentiated needs, the way country-level governance and social responsibility contribute to the ensuring of sustainable economic development is a concern for all the actors of the economic sphere. The aim of this paper is to test the causal linkages between the quality of country-level governance, economic growth and a well-known indicator of economic sustainable development, for a large panel of world-wide countries for a period of 10 years (2006-2015). While there are some prior studies that have argued the bidirectional causality between good public governance and economic development, this study intends to provide a new focus on the relationship between country-level governance and economic growth, on one hand, and between country-level governance and adjusted net savings, as a selected indicator of economic sustainable development, on the other hand. Four hypotheses on the causal relationship between good governance, economic growth and sustainable development were tested by using Granger non-causality tests. Our findings resulting from Granger non-causality tests provide reasonable evidence of Granger causality from country-level governance to economic growth, but from economic growth to country-level governance, the causality is not confirmed. In what regards the relationship between country-level governance and adjusted net savings, the bidirectional Granger causality is not confirmed. The main implication of our study is that improving economic growth and sustainable development is a very challenging issue, and the impact of macro-level factors such as country-level governance should not be neglected.
\end{abstract}

Keywords: economic sustainable development; country-level governance; economic growth; gross domestic product; adjusted net savings as a percentage of gross national income; Granger non-causality test; vector autoregressive model

\section{Introduction}

There are a multitude of views in the theoretical and empirical literature regarding the relationship between country-level governance and different dimensions of sustainable development. Country-level governance or so called good governance is considered by some authors [1] (p. 558) as "the new approach that recognizes the role of the state in the economy where the joint participation of state and non-state actors, civil society and private sector, is essential in the process of public governance". No doubt, the role of country-level governance is significant for economic growth and business development, particularly if we keep in mind the main features that characterize good governance 
such as: accountability, transparency in policy making, an effective legislative framework where property rights are clearly defined and the predictability of business transactions is ensured [2].

There is a wide range of views in previous scholarship literature concerning the linkages between country-level governance and different stages of the business environment development. Some authors [3] state that the impact of good governance on economic development is supported by the premise that one expects that an economy with a reduced level of bureaucracy, with a great preoccupation for the quality of regulation and with effective tools to control corruption, will be able to provide an effective business framework which could increase economic growth. Moreover, some studies [4] show that good country-level governance requires accountability and transparency in elaborating economic policies and the rule of law, while all these key elements ensure relevant premises for generating economic performance and sustainable development. Other authors [5] state that there is a significant influence between the quality of the regulatory framework and economic performance at micro- and macro-levels. The causal link between business performance and the quality of governance was also confirmed by the results of other studies [6]. Moreover, it is demonstrated [7] that resource allocation is directly influenced by the quality of governance.

On the other hand, in the academic literature not everybody is really convinced about the significance of good country-level governance for economic sustainable development goals [1]. For instance, some authors [8] argued that it is not absolutely clear if good governance has an impact on the society's economic performance, considering that "replacing bad institutions with good ones may possibly produce worse outcomes for society". This idea is argued with some worldwide examples (Tunisia, Morroco, Egypt, Ukraine) where the attempts to change a bad governance framework with a good one did not necessarily ensure the premises for an economic growth and sustainable development $[1,8]$.

The objective of this study is to explore the causal relationship between country-level governance measured through the World Bank governance indicators, economic growth measured through the most widely used indicator in previous literature such as the Gross Domestic Product, and sustainable development measured through adjusted net savings (\% of GNI), by using Granger non-causality test. Although earlier empirical studies have argued the impact of good governance on economic growth and sustainable development $[5,6,9]$, this paper differs from the previous studies by analyzing the causal linkage between good governance, economic growth and sustainable development, in the attempt to answer the questions: Does governance cause economic growth? Or economic growth causes good country-level governance? Does country-level governance causes sustainable development? Or sustainable development causes good country-level governance? Our findings suggest that country-level governance does influence the Gross Domestic Product (GDP) as a selected indicator of economic growth, but not vice versa. On the other hand, our study provides reasonable evidence that the causal relation between country-level governance and adjusted net savings, as a selected indicator for sustainable development is not truly confirmed.

The study is structured as follows. The next section includes a literature review of studies which have investigated the relationship between country-level governance, economic growth and sustainable development. Section 3 discusses the research design and data used for developing this empirical survey. The empirical results and findings are presented and analyzed in Section 4. Section 5 presents the concluding section where the main conclusions and perspectives for further research are offered. We hope that this study will provide the necessary context for developing constructive debates on the bidirectional causality between country-level governance, economic growth and sustainable development and, why not to further identify the most important factors for the existence/inexistence of this causality. 


\section{Background Literature}

\subsection{Good Country-Level Governance Indicators}

The concept of good country-level governance has been a subject of major interest for worldwide researchers in the early 1990s, when some scholars emphasized that "underdevelopment has been primarily attributed to problems of poor governance." [10] (p. 437), while in the vision of the World Bank poor development is argued to result primarily from poor governance [11]. Other researchers define good country-level governance as being "the favourable political framework conditions for social, ecological and market oriented development as well the responsible use of political power and public resources by the state" [12] (p. 27).

The concept of governance was defined by the World Bank in its working paper "Governance and Economy: a review" as a neutral concept, meaning "the political direction and control exercised over the actions of the members, citizens or inhabitants of communities, societies and states" [13] (p. 3). According to the specialists of the World Bank [13], the impact of political dimensions of the country-level governance on economic performance cannot be neglected. Political accountability, transparency and an effective rule of law are some of the most meaningful characteristics of good governance that influence the economic development and the quality of business environment which should be focused on providing economic performance. The concept of country-level good governance became more and more relevant when various international aid agencies understood that the poor quality of governance structures across many developing economies was a significant obstacle to the increasing of their economic performance [10].

Because of the increasing interest of policymakers and scholars in the field of governance, in the academic literature there have been identified different indices or indicators for measuring the most relevant dimensions of country-level governance [14-17]. The most widely used country-level governance indicators are the ones developed by the World Bank [14,18], based on a methodology using an unobserved components model. This model combined the information from different sources developing a subset of six good governance indicators through the quality of country-level governance which was measured for a large panel of worldwide countries. Despite the view of some critics [19] it is quite problematic to obtain "a one-best-way" model for good country-level governance that fits any region or country, particularly due to the differences between various models of effective governments such as the Swedish model, the German model or the Anglo-Saxon model. Six governance indicators (1. Voice and Accountability; 2. Political Stability and Absence of Violence; 3. Government Effectiveness; 4. Regulatory Quality; 5. Rule of Law and 6. Control of Corruption) have been identified. These indicators developed by the World Bank are the most used in the academic literature. One major advantage of using these governance indicators is their utility in making comparisons for larger samples of countries, thus having the opportunity to develop very complex cross-country surveys. Another advantage of these indicators is that they manage to integrate the major key coordinates of the country-level governance. Consequently, next in our paper, we use the governance indicators as measured by the World Bank in an aggregate form.

\subsection{The Country-Level Governance Versus Economic Growth—Background Theory and Hypothesis Development}

One of the most used indicators in the academic literature for measuring economic growth is the Gross Domestic Product (GDP). According to the definition of the World Bank, GDP represents the sum of value added by all its producers, while value added is the value of the gross output less the value of intermediate goods and services consumed in the process of production, before accounting for consumption of fixed capital in production. According to some authors [1,20], after the World War II, the main objective for advanced economies was to maintain a specific target of GDP growth, starting from the assumption that a high level of GDP will automatically bring in a higher level for economic welfare and quality of life. Subsequently, many scholars started to underline the differences 
between economic growth and sustainable development [1]. While some authors [21,22] suggest that this indicator cannot compress and measure the reality of the conditions of people's lives and the multivariate aspects supposed by a certain quality of life cannot be measured, other scholars argue that focusing only on economic growth for developing economies is not sufficient for ensuring a sustainable development, characterized by a low level of poverty and an increasing quality of life [23]. The same author argues that for countries with a low level of development, economic growth measured by GDP per capita is relevant for reducing poverty and improving the quality of life, but still only economic growth is not sufficient for ensuring sustainable development. Therefore, other indicators have been proposed in the latter years as a better alternative to GDP for measuring the progress of economic welfare and sustainable development.

The relationship between country-level governance and economic growth has been widely discussed in the previous literature, even if there are some opposing opinions among specialists. The correlation between the quality of economic and political institutions and economic performance has been the objective of many cross-country empirical studies [6,24-26], while only few papers are addressing the impact of bureaucratic professionalization and effectiveness of government on economic growth $[24,27]$. There is a general consensus among economists and policymakers about the role of institutions in influencing economic development, while some author admits that "there is increasing recognition that corruption and other aspects of poor governance and weak institutions have substantial, adverse effects on economic growth" [28] (p. 3). In the attempt to answer the question of how important is good country-level governance for economic growth, another author admits the answer is best highlighted by the "oft-cited aphorism that good governance promotes growth and that growth further improves governance" [29] (p. 29). The same author admits there are a lot of econometric papers whose findings emphasize a strong correlation between long-term economic development and good country-level governance, thus the quality of governance definitely influences long-run economic performance outcomes.

The strong positive correlation across countries between GDP per capita and the quality of governance was also admitted by the World Bank [9]. Even more, researchers from the World Bank proposed in their working papers an empirical strategy to analyze this correlation from two directions, namely: (a) a strong positive causal effect running from a better quality of country-level governance to GDP per capita; and (b) a weak and even negative causal effect running in the opposite direction from GDP per capita to the quality of governance. Their results [9] provide sufficient evidence on the significance of good country-level governance for economic performance. On the other hand, the same study points out the non-existence of "virtuous circles" [9] (p. 1) in which a higher GDP per capita determines further amelioration in the quality of governance.

On the other hand, there are some studies where the linkage between economic growth and good governance is contradicted. For instance, some authors $[1,30]$ argue this conclusion with the examples of certain countries such as Cambodia, China and Vietnam in which the economic growth is clearly demonstrated despite of the lack of good country-level governance. Another author [31] argues that in spite of empirical findings which point out a very weak positive correlation between the quality of country-level governance and economic growth, still we should not promote the false perception that governance does not matter that much for economic performance.

There are few studies that investigated the governance-to-economic performance causal relationship and contradict the conclusions resulted from most of the previous papers which argue the positive influence of good governance on economic development [24]. The author of this study confirms a positive correlation between governance and economic growth, but he concludes that is not necessary to consider the quality of governance as a key factor, determinant for economic performance. Even more, the same author has demonstrated a positive influence of economic growth on subsequent quality of governance, therefore he suggests that more attention should be paid to analyze the possible reverse causality between governance and economic growth, particularly in cross-country analyses [24]. 
No doubt, enhancing the quality of country-level governance is significant for economic growth and business development, but some questions still remain without well-argued answers: How significant is country-level governance for economic growth? How important is economic growth for good country-level governance?

Given the synthesis of previous studies, we appreciate that greater attention should be paid to analyze the reverse causality between good governance and economic growth. Thus, we formulated the following hypotheses to be tested in our analysis:

Hypothesis 1 (H1). Country-level governance (as an aggregated variable), significantly contributes to increase the value of the Gross Domestic Product, as a selected indicator of economic growth.

Hypothesis 2 (H2). Improvement in the value of the Gross Domestic Product, as a selected indicator of economic growth causes a subsequent improvement in the quality of country-level governance.

\subsection{The Country-Level Governance Versus Sustainable Development-Background Theory and Hypothesis Development}

The concept of sustainable development is a subject of major concern for various stakeholders, policymakers and for scientists as well. While the literature in the field abounds in various definitions for sustainable development [32,33], a simple definition of this concept from the point of view of economists was issued in a working paper authored by researchers from the World Bank according to which: "a development path is sustainable if total welfare does not decline along the path" [33] (p. 1). A major point of reference for sustainable development is given by the publication in 1987 of the Brundtland Commission Report entitled Our Common Future [22]. This report was issued by The World Commission on Environment and Development chaired by the Prime Minister of Norway Gro Harlem Brundtland, thus earning the name of the "Brundtland Commission Report". The Brundtland Report introduced a new dimension in what regards the concept of economic development by raising the issue of sustainable development on the global agenda. According to this report, sustainable development is the ability "to ensure that it meets the needs of the present without compromising the ability of future generations to meet their own needs [34] (p. 16). Ensuring proper sustainable development includes economic, as well as social and environmental dimensions into an interdisciplinary approach of this concept, while acquiring sustainable development is based on a process of generating and maintaining wealth. Economic, social and environmental issues should be equally and completely integrated in the process of enhancing development.

By considering the economic dimensions as well as the social and environmental conditions that should be incorporated in the spectrum of these multidimensional indicators, many sustainability indicators have been developed to measure the progress of economic, social and environmental dimensions. The target level of such indicators should normally be used to guide policymakers in their political and social activities. The range of indicators used in measuring the progress of sustainable development is very high; therefore, in the following, by considering its relevancy for the purpose of our paper, one major sustainable economic development indicator was selected and presented.

The indicator Genuine Savings or so-called Adjusted Net Savings is considered as one of the most appropriate indicator for measuring the progress of sustainable development, because of its ability to encompass information of the country's economic, social and environmental development [35]. The possibility to incorporate into one single indicator information about economic, social and environmental development is considered as a major advantage of this sustainable indicator. The Adjusted Net Savings indicator is designed to measure real savings in produced, natural and human capital, as it recalculates national savings derived from the standard national accounting measure of gross saving by making adjustments which refer to the depreciation (consumption) of produced assets, the depletion of a variety of national resources, the value of global environmental pollution and the current public expenditure on education (or investment in human capital which is perceived as saving 
rather than consumption) [36]. According to the World Bank researchers [33] the first cross-country application of this indicator built on the concepts of green accounting methods is emphasized by a study [37] that underlined that many countries seem to be unsustainable because their savings are inferior to the aggregated depreciation of human and natural capital combined with natural resource depletion. According to the indicator's description issued by the World Bank, Adjusted Net Savings (ANS) is a relevant indicator for appreciating the country's sustainability because it measures the change in value of a specified set of assets, excluding capital gains. If a country's ANS is positive this means that social welfare and the quality of life for people from that country is increasing. Otherwise, in case of negative ANS, one can interpret that this country is on an unsustainable direction.

The linkage between country-level governance and sustainable development has been widely discussed in the previous literature, even if there are some opposing views among specialists. The correlation between the quality of political institutions, effective governance and sustainable development has been the objective of many cross-country empirical studies $[6,25,26]$, while only few papers are addressing the impact of bureaucratic professionalization and government efficiency on sustainable development [27]. In the opinion of some authors [38-40], good governance has to be interpreted as significant problematic for ensuring sustainable development, because good governance requires real improvements for all dimensions of the public sector, from institutions that set the rules for economic transactions, to decision-making authorities that decide the principles of resources allocation, to administrative structures that provide goods and services to citizens.

One study concludes that for Scandinavian countries characterized by a high level of good governance, an increasing level of trust in governance structures and lower inequalities are more receptive to the social needs, while they dispose of sufficient financial resources to achieve a high level of economic sustainable development [41]. The same study highlights that there are some countries like Germany with a high level of good governance, but a medium level of trust in country-level governance mechanisms, while the level of economic growth is lower compared to Scandinavian countries and income distribution is a bit less equal. On the other hand, the findings of the same study conclude that former Socialist countries record low indicators of country-level governance, lower level of economic growth, higher income inequalities which negatively affect the social cohesion [41,42].

Other authors suggest that good governance may be necessary but not sufficient for economic sustainable development [43], because many developing countries don't have sufficient financial and administrative resources in order to promote a coherent and wide reform of country-governance [44]. But even so, the significance of good country-level governance cannot be neglected, especially if we keep in mind the role of appropriate institutions that should ensure the premises for a real sustainable development [45]. As the same author points out, an ineffective control of corruption, bureaucratic inefficiency, inefficient regulatory framework contribute to the undermining of the capacity of governance structures to facilitate sustainable development. Thus, good policies and the effectiveness of governance structures are required to ensure sustainable development [45]. Other authors [46] (p. 410) argue that "problems that are now exclusively associated with sustainable development might well be problems of governance for sustainable development", because the premises for ensuring sustainable development cannot be accomplished without good governance because of its major characteristic, namely to achieve common goals by collective actions, with transparency and accountability. The same authors points out the relationship between the country-level governance concept and the characteristics of sustainable development which requires the involvement of a plurality of parties that have to adequately respond to the requirements of social complexity and a proper institutional setting because many sustainability projects and initiatives are negatively affected by a "weak institutionalization", therefore structural improvements in the public sector are strongly required [46]. Thus, governance for sustainable development represents a huge but unavoidable challenge, because governance structures and practices need to be properly designed so that to foster, guide and coordinate the activities of a wide range of actors on a vast complex of social, economic and environmental issues [47]. 
Many studies have argued the significance of country-level governance for sustainable development, but still little empirical arguments have been provided by the papers in the field, to argue the causal linkage between the quality of country-level governance and sustainable development, therefore we have set up our next hypotheses:

Hypothesis 3 (H3). Country-level governance (as an aggregated variable) significantly contributes to the increase in the value of adjusted net savings, (\% of GNI), as a selected indicator of sustainable development.

Hypothesis 4 (H4). Improvement in the value of adjusted net savings (\% of GNI), as a selected indicator of sustainable development causes a subsequent improvement in the quality of country-level governance.

\section{Research Methods and Data}

\subsection{Research Methods}

This study uses annual data from 2006 to 2015 on the quality of country-level governance and selected indicators of sustainable development to test with the procedure of bivariate causality testing based on Granger non-causality [48] for both research proposed directions: (i) from country-level governance to economic growth and from economic growth to country-level governance; and (ii) from country-level governance to sustainable development and from sustainable development to country-level governance, by using a Toda-Yamamoto approach [49]. According to some authors [50], using a Toda-Yamamoto approach involves an estimation of a vector autoregressive model (VAR) in levels, while this method minimizes the risks associated with incorrect identification of the order of integration of the respective time series and co-integration among selected variables to be used in the model. More exactly, applying Toda-Yamamoto long-run causality approach artificially increases the correct order of the VAR, lag length $\mathrm{K}$, by the maximum order of integration, Dmax and ensures that the usual test statistics for Granger non-causality have the standard asymptotic distribution [50,51].

The central idea of the Granger test is that one can assume two stochastic processes $\mathrm{Xt}$ and $\mathrm{Yt}$. One can say that variable Xt Granger-causes variable Yt (or in other words has predictive power) if and only if the lagged values of both $\mathrm{Yt}$ and $\mathrm{Xt}$ have better forecasting ability on $\mathrm{Yt}$ than just the lagged values of Yt on itself [48]. Considering the particularities of this method, it was necessary to develop a model which should contain more past information; therefore, for our analysis an extended period has been selected, taking into account the availability of the data. For each pair of hypotheses to be tested, we will consider that VAR has two equations, one for $\mathrm{X}$ and one for $\mathrm{Y}$. We will test the hypothesis stating that the coefficients of only the first $p$ lagged values of variable $X$ are zero in the $Y$ equation, by using a standard Wald test. Then, we will do the same thing for the coefficients of the lagged values of variable $\mathrm{Y}$ in the $\mathrm{X}$ equation. Finally, the rejection of the null hypothesis implies a rejection of Granger non-causality, and this rejection suggests the presence of Granger causality.

Starting with the beginning of the 21st century, the Granger causality method has become more and more used in many research fields, but particularly in econometrics and economics, but also in other fields from medical areas [52]. The same author concludes that the number of published studies, which have used the Granger causality method, has increased between years 2001 and 2011 more than six times [52]. This growing popularity is argued by some authors due to the specific of the Granger causality method, which is described as "the most influential explicit approach to causality in economics" [53] (p. 12).

\subsection{Data}

For measuring the quality of governance, we have selected the data referring to the indicators of governance for the selected period and were available from the report issued by the World Bank within the project "The Worldwide Governance Indicators" which is based on information provided by more than 40 data sources delivered by over 30 various organizations worldwide and it has been updated 
on an annual basis since 2002. Considering the methodology developed $[14,18]$ this long-term project developed by the World Bank attempts to measure the quality of governance through six governance aggregate indicators such as: 1 . Voice and Accountability; 2. Political Stability and Absence of Violence; 3. Government Effectiveness; 4. Regulatory Quality; 5. Rule of Law and 6. Control of Corruption. All these six aggregate indicators are developed based on the methodology described in their previous companion paper "Aggregating Governance Indicators" [14] by using an unobserved components model, which is similar to six relevant characteristics for the concept of good country-level governance as follows:

- Voice and accountability—consists of various aspects of the political process, civil liberties and political rights, assessing the extent to which citizens are able to take part in the selection of their governance structures.

- Political stability and absence of violence-combines several indicators which measure the potential likelihood that the government in exercise to be replaced through unconstitutional or violent methods.

- Government effectiveness-measures the perception over the inputs necessary for effective governance, such as the quality of public service provision, the competence of civil servants, the level of bureaucracy, and the independence of the civil services from political interferences and the credibility of the government.

- Regulatory quality—captures the effects of the policies which are felt as market-unfriendly such as price controls or inadequate bank supervisions or excessive regulation which might negatively affect business development.

- Rule of law-includes some indicators that estimate the extent to which the public and citizens have confidence in and abide by the rules of society, containing the effectiveness of the judiciary systems and the security of property rights.

- Control of corruption - summarizes the public's perception on the control of corruption, including various forms of public power exercises for illegally private gains such as "additional payments to get things done", but also its negative influences on the business environment.

Because the six governance indicators are highly correlated, they cannot be simultaneously included in a panel analysis for reasons of multicollinearity; consequently we used an un-weighted average of the six World Bank governance indicators to measure the quality of country-level governance.

To measure economic growth we used data for one of the most used indicator such as the Gross Domestic Product (GDP) as defined by the World Bank. To measure sustainable development we used data on a selected indicator such as Adjusted Net Saving (ANS) as a percentage of Gross National Income (GNI). Both these selected indicators were retrieved from the World Development Indicators [54]. This World Bank database is the product of a collaborative partnership of international agencies, statistical offices of more than 200 national economies. One of its major goals is to annually present a wide range of indicators that are aligned with the target of the Sustainable Development Goals. For instance, in September 2015, the leaders of 193 countries agreed on a set of 17 Sustainable Development Goals to guide global action for the next 15 years [54]. The authors of this World Bank Development Indicators Report insisted on properly select key indicators for each of the 17 goals, in order to identify significant trends and future challenges.

We have extracted data for the selected indicators for the period 2006-2015. The initial sample consisted of 190 countries, considering the availability of the data, but then we had to exclude 54 countries for which there were missing data for GDP and Adjusted Net Savings. Next, in Table 1 there is disclosed a synthesis of the selected variables and used databases. 
Table 1. Description of variables and data sources.

\begin{tabular}{|c|c|c|c|}
\hline Variable Name & Symbol & Source & Description \\
\hline $\begin{array}{l}\text { Country-level } \\
\text { governance }\end{array}$ & GOV_AVG & [55] & $\begin{array}{l}\text { An aggregated governance measure which consists of an average value of } \\
\text { six good country-level governance indicators calculated within the } \\
\text { Worldwide Governance Indicators: } 1 \text {. Voice and Accountability; } \\
\text { 2. Political Stability and Absence of Violence; } 3 \text {. Government Effectiveness; } \\
\text { 4. Regulatory Quality; } 5 \text {. Rule of Law and } 6 \text {. Control of Corruption. }\end{array}$ \\
\hline $\begin{array}{l}\text { Gross Domestic } \\
\text { Product }\end{array}$ & GDP & [54] & $\begin{array}{l}\text { Gross domestic product (GDP) is the market value of all goods and services } \\
\text { produced within a country in a given period. It is a measure of a country's } \\
\text { economy as far as money is involved. }\end{array}$ \\
\hline $\begin{array}{l}\text { Adjusted Net } \\
\text { Saving (ANS) as } \\
\text { a percentage of } \\
\text { Gross National } \\
\text { Income (GNI) }\end{array}$ & ANS & [54] & $\begin{array}{l}\text { Adjusted net saving is derived from the standard national accounting } \\
\text { measure of gross saving by making four adjustments: (i) consumption of } \\
\text { fixed capital is deducted to obtain net national saving; (ii) current public } \\
\text { expenditure on education is added to account for investment in human } \\
\text { capital; (iii) estimates of the depletion of a variety of natural resources are } \\
\text { deducted to reflect the decline in asset values associated with extraction } \\
\text { and depletion; (iv) deductions are made for damages from carbon dioxide } \\
\text { and particulate emissions. The indicator is then computed by dividing } \\
\text { ANS by GNI. }\end{array}$ \\
\hline
\end{tabular}

\section{Results and Discussions}

\subsection{Testing the Selected Time-Series for Integration}

The first step of the Toda-Yamamoto approach on Granger causality is to test each of the time-series selected (GDP, ANS and GOV_AVG) in order to investigate the stationarity issue and the possible presence of unit roots in series and to determine their order of integration [49]. According to the Toda-Yamamoto application of Granger causality, in most applications, it is not known a priori whether the selected variables are integrated, cointegrated, or (trend) stationary. Therefore, pre-tests for a unit-roots and cointegration in the economic time series (and estimation of the cointegrating vector(s) if there is cointegration) are usually required before estimating the VAR model [49]. We suppose the null hypothesis that if there is unit root then it means the tested time-series is not stationary. The rejection of the null hypothesis means the validation of an alternative hypothesis: there is no unit root in time-series, therefore this series is stationary. We reject the null and accept the alternative hypothesis when the $p$-value is less than or equal to a specified significance level, often $0.05(5 \%)$, or $0.01(1 \%)$ and even 0.1 (10\%). We used panel data unit root test Levin-Lin-Chu [56], Im-Pesaran-Shin [57] and Augmented Dickey-Fuller (ADF-Fisher) [58] panel data unit-root test for the individual time series and their differences were used. Subsequently, for each t-tests in series the lag-length was chosen to ensure that the residuals were white noise. Next, in Table 2 there are presented the results of $t$-tests applied for the GDP time-series.

Table 2. Panel unit-root test for the Gross Domestic Product (GDP) time series.

\begin{tabular}{|c|c|c|c|c|}
\hline Method & Statistic & Prob. ** & Cross-Sections & Obs \\
\hline Levin, Lin \& Chu $\mathrm{t}^{*}$ & -31.1751 & 0.0000 & 138 & 1100 \\
\hline Breitung t-stat & 0.65535 & 0.7439 & 138 & 962 \\
\hline \multicolumn{5}{|c|}{ Null: Unit Root (Assumes Individual Unit Root Process) } \\
\hline Im, Pesaran and Shin W-stat & -2.65524 & 0.0040 & 138 & 1100 \\
\hline ADF-Fisher Chi-square & 426.408 & 0.0000 & 138 & 1100 \\
\hline PP_Fisher Chi-square & 365.370 & 0.0002 & 138 & 1238 \\
\hline
\end{tabular}

Panel unit root test: Summary Series: GDP. Sample: 2006-2015. Exogenous variables: Individual effects, individual linear trends. User-specified lags: 1. Newey-West automatic bandwidth selection and Bartlett kernel. * Probabilities for Levin, Lin \& Chu tests assume asymptotic normality. ${ }^{* *}$ Probabilities for Fisher tests are computed using an asymptotic Chi-square distribution. All other tests assume asymptotic normality. 
In what regards the GDP time-series, the Levin-Lin-Chu $\mathrm{t}$ * statistics for common unit root $p$-value $<0.05$ we fail to accept the null hypothesis, we can assume that the process does not have a common unit root and the GDP data is stationary. The results of Im-Pesaran-Shin and ADF-Fisher t-tests for individual unit root $p$-value $<0.05$ we fail to accept the null hypothesis, we can assume that the process does not have an individual unit root and the GDP data is stationary. Next, Table 3 presents the results of $t$-tests for the GOV_AVG time-series.

Table 3. Panel unit-root test for the Country-level Governance GOV_AVG time series.

\begin{tabular}{lllll}
\hline Method & Statistic & Prob. ${ }^{* *}$ & Cross-Sections & Obs \\
\hline Levin, Lin \& Chu t & -14.7503 & 0.0000 & 138 & 1102 \\
Breitung t-stat & 5.63647 & 1.0000 & 138 & 964 \\
\hline \multicolumn{2}{l}{ Null: Unit root (assumes individual unit root process) } & & \\
\hline Im, Pesaran and Shin W-stat & 0.76483 & 0.7778 & 138 & 1102 \\
ADF-Fisher Chi-square & 279.720 & 0.4262 & 138 & 1102 \\
PP-Fisher Chi-square & 435.186 & 0.0000 & 138 & 1240 \\
\hline
\end{tabular}

Panel unit-root test: Summary Series: GOV_AVG. Sample: 2006-2015. Exogenous variables: Individual effects, individual linear trends. User-specified lags: 1. Newey-West automatic bandwidth selection and Bartlett kernel. * Probabilities for Levin, Lin \& Chu tests assume asymptotic normality. ${ }^{* *}$ Probabilities for Fisher tests are computed using an asymptotic Chi-square distribution. All other tests assume asymptotic normality.

As for the GOV_AVG time-series, the results of the t-tests are somehow different. By applying the Levin-Lin-Chu $t *$ statistics for common unit-root $p$-value $<0.05$ we fail to accept the null hypothesis, thus we can assume that the process does not have a common unit root and the GOV_AVG data is stationary. On the other hand, the results of Im-Pesaran-Shin and ADF-Fisher t-tests for individual unit-root $p$-value $>0.05$ we fail to reject the null hypothesis, so we can assume that the process does have an individual unit root and the GOV_AVG data is not stationary. A stationary time series is one whose statistical properties such as mean, variance, autocorrelation, etc. are all constant over time. If the mean, variance, and autocorrelations of the original series are not constant in time, perhaps the statistics of the changes in the series between periods or between seasons will be constant. Such a time-series is said to be difference-stationary. Therefore, GOV_AVG is not stationary, thus we apply first order difference to make stationary at $d=1$. The first difference of a time series is the series of changes from one period to the next. If $Y t$ denotes the value of the time series $Y$ at period $t$, then the first difference of $\mathrm{Y}$ at period $\mathrm{t}$ is equal to $\mathrm{Yt}-\mathrm{Yt}-1$.

Finally, Table 4 discloses the results of t-tests for the ANS time-series.

Table 4. Panel unit-root test for the Adjusted Net Savings (ANS) time-series.

\begin{tabular}{lllll}
\hline Method & Statistic & Prob. $^{* *}$ & Cross-Sections & Obs \\
\hline Levin, Lin \& Chu t & -26.0526 & 0.0000 & 138 & 1102 \\
Breitung t-s tat & 2.08532 & 0.9815 & 138 & 964 \\
\hline \multicolumn{7}{l}{ Null: Unit Root (Assumes Individual Unit Root Process) } & & \\
\hline Im, Pesaran and Shin W-stat & -1.42411 & 0.0772 & 138 & 1102 \\
ADF-Fisher Chi-square & 389.535 & 0.0000 & 138 & 1102 \\
PP-Fisher Chi-square & 575.742 & 0.0000 & 138 & 1240 \\
\hline
\end{tabular}

Panel unit-root test: Summary Series: ANS; Sample: 2006-2015. Exogenous variables: Individual effects, individual linear trends. User-specified lags: 1 . Newey-Wes $t$ automatic bandwidth selection and Bartlett kernel. * Probabilities for Levin, Lin \& Chu tests assume asymptotic normality. ${ }^{* *}$ Probabilities for Fisher tests are computed using an asymptotic Chi-square distribution. All other tests assume asymptotic normality.

With respect to the ANS time-series, the Levin-Lin-Chu $t *$ statistics for common unit-root $p$-value $<0.05$ we fail to accept the null hypothesis, so we can assume that the process does not have a common unit root and the ANS data is stationary. In what regards the results of Im-Pesaran-Shin for 
individual unit-root $p$-value $<0.10$ and the ADF-Fisher t-tests for individual unit-root $p$-value $<0.05$ we fail to accept the null hypothesis, we can assume that the process does not have an individual unit root and the ANS data is stationary.

\subsection{Results of the Granger Non-Causality Tests for GDP_GOV_AVG}

The first bidirectional relationship according to Hypotheses 1 and 2 proposed to be tested in our study is between GDP and GOV_AGV and vice versa. In order to apply the Toda-Yamamoto's approach of the Granger non-causality test, we summarize the GDP_GOV_AVG model in the following VAR system:

$$
\begin{gathered}
(\mathrm{DGDP})_{t}=\alpha_{1}+\sum_{i=1}^{n} \beta_{1, i}(D G D P)_{t-i}+\sum_{i=1}^{n} \gamma_{1, i}\left(D G O V_{-} A V G\right)_{t-i}+\varepsilon_{1, t} \\
(\text { DGOV_AVG })_{t}=\alpha_{2}+\sum_{i=1}^{n} \beta_{2, i}\left(D G O V \_A V G\right)_{t-i}+\sum_{i=1}^{n} \gamma_{2, i}(D G D P)_{t-i}+\varepsilon_{2, t}
\end{gathered}
$$

where $\varepsilon_{1, t}$ are $\varepsilon_{2, t}$ are independently and normally distributed error terms, $\alpha_{1}, \alpha_{2}$, are constants and $\beta_{1, \mathrm{i}}, \beta_{2, i}, \gamma_{1, i}, \gamma_{2, i}$ for $i=1, \ldots ., N$ are coefficients.

The next step in testing Granger non-causality is to see whether the time-series are cointegrated. The cointegration of two time-series means that a linear combination of two non-stationary processes is stationary, so that it has a constant mean and variance [59]. If two time-series are cointegrated this means they have an inner long run relationship, thus co integrated series $\mathrm{Xt}$ and $\mathrm{Yt}$ will move together over time in a similar direction, while their variation over time is to some extend foreseeable. $\mathrm{Or}$, as some author admits, their linear combination of $\mathrm{Xt}$ and $\mathrm{Yt}$ will not divert far from its long-run equilibrium [59]. Because, the cointegration of two time-series in a bivariate VAR model it is suspected to provide incorrect evidence about Granger causality, it is necessary to modify the VAR model by adding an error-correction term $[59,60]$. Thus, in case of cointegration of time-series we will use the Vector Error Correction Model (VECM).

To test whether two time-series are cointegrated, we apply the Pedroni residual cointegration test $[61,62]$. A precondition for running a panel cointegration test is that the variables must be stationary at the same level. Because country-level governance is stationary at $d=1$, we convert each variable into first differenced so that they all become stationary of the same order. The results of the Pedroni residual cointegration tests are disclosed in Table 5.

Table 5. The Pedroni residual co-integration test.

\begin{tabular}{lllll}
\hline \multicolumn{5}{l}{ Alternative Hypothesis: Common AR Coefficients. (Within-Dimension) } \\
\hline & Statistic & Prob. & Weighted Statistic & Prob. \\
\hline Panel v-Statistic & -10.97703 & 1.0000 & -11.31195 & 1.0000 \\
Panel rho-Statistic & 3.402484 & 0.9997 & 3.712041 & 0.9999 \\
Panel PP-Statistic & -17.49013 & 0.0000 & -18.13403 & 0.0000 \\
Panel ADF-Statistic & -14.41920 & 0.0000 & -14.37476 & 0.0000 \\
\hline Alternative Hypothesis: Individual AR Coefficients. (Between-Dimension) \\
\hline \multicolumn{5}{l}{} \\
\hline Group rho-Statistic & Statistic & Prob. & \\
Group PP-Statistic & 7.334806 & 1.0000 & \\
Group ADF-Statistic & -20.67414 & 0.0000 & & \\
\hline
\end{tabular}

Pedroni Residual Co-integration Test Series: DGDP_DGOV_AVG. Sample: 2006-2015. Included observations: 1030. Cross-sections included: 103. Null Hypothesis: No cointegration. Trend assumption: Deterministic intercept and trend. Automatic lag length selection based on SIC with a max lag of 0 . Newey-West automatic bandwidth selection and Bartlett kernel. 
After analyzing the results from Table 5, for $p$-value $<0.05$ tests, we reject the null hypothesis and say that the GDP and the GOV_AVG time-series are cointegrated with the assumption of a deterministic trend and intercept. As we mentioned before, because we are testing for Granger non-causality and the series are co integrated, we are using the Vector Error Correction Model (VECM). Because the number of lags has a significant influence on the results of the Granger non-causality tests, we need to establish the correct number of lags. There are more techniques that could be applied in order to determine the length of a series of past values in a model $[52,63]$. Next, in Table 6, there are disclosed the selected techniques that we used to determine the lag length.

Table 6. Test for selecting the number of lags.

\begin{tabular}{ccccccc}
\hline Lag & LogL & LR & FPE & AIC & SC & HQ \\
\hline 0 & -642.6682 & NA & 936.4316 & 12.51783 & 12.56899 & 12.53855 \\
1 & -620.1789 & 43.66865 & $653.9897^{*}$ & $12.15881^{*}$ & $12.31229 *$ & $12.22098^{*}$ \\
2 & -619.8182 & 0.686332 & 701.9610 & 12.22948 & 12.48528 & 12.33309 \\
3 & -618.4695 & 2.514142 & 739.2423 & 12.28096 & 12.63908 & 12.42601 \\
4 & -614.0268 & 8.108903 & 733.2632 & 12.27237 & 12.73280 & 12.45886 \\
5 & -610.5306 & 6.245605 & 741.0212 & 12.28215 & 12.84491 & 12.51008 \\
6 & -609.4635 & 1.864792 & 785.2881 & 12.33910 & 13.00418 & 12.60848 \\
7 & -607.6735 & 3.058724 & 820.9211 & 12.38201 & 13.14941 & 12.69283 \\
8 & -600.7698 & $11.52850 *$ & 777.4100 & 12.32563 & 13.19534 & 12.67789 \\
\hline
\end{tabular}

VAR Lag Order Selection Criteria. Endogenous variables: DGDP;DGOV_AVG. Exogenous variables: C. Sample: 2006-2015. * indicates lag order selected by the criterion. LR: sequential modified LR test statistic (each test at $5 \%$ level); FPE: Final prediction error; AIC: Akaike information criterion; SC: Schwarz information criterion; HQ: Hannan-Quinn information criterion.

According to the various information criteria presented by Table 6, one can remark that it should have a maximum lag length of 1 for each variable. Because the series are cointegrated, in Table A1 from Appendix A there are disclosed the results obtained by applying the Vector Error Correction Model (VECM). Each column represents a model with dependent variables and the rows represent the endogenous variables. We added constant as exogenous variables. At first we were trying to see if for Model 1 there is short term effect on GDP from its own lags and the lags of the independent variables GOV_AVG. Then, for Model 2, one can note there is a short term effect on GOV_AVG from its own lags and the lags of the independent variables (GDP).

According to the Table A1 from Appendix A, R-square (0.451) from column 1 explains the variance $-45 \%$ of the model 1, when GDP on its lags and the lags of GOV_AVG, while R-square (0.465) from column 2 explains the variance $-47 \%$ of the model 2 when GOV_AVG on its lags and the lags of GDP. From the equations below we can't asses if the coefficients of the model are statistically significant, thus, it is necessary to test and estimate the coefficients using the OLS (Ordinary Least Square) regression, as it is shown next in Table 7.

One can note from Table 7 that C(1) for model 1 and C(7) for model 2 are the error correction terms, when these are negative in coefficient and significant then we can say that there is a long run causality running from independent to dependent. There would be a speed of adjustment towards long-run equilibrium.

For model $1, \mathrm{C} 1=-0.005, p$-value $<0.05$, one can conclude that there is a long run causality running from GOV_AVG to GDP. For model $2, C 7=-0.00000275, p$-value $<0.05$ there is a long run causality running from GDP to GOV_AVG.

Considering the significance of the $p$-values obtained as result of testing for Granger causality by using the Vector Error Correction Estimates Model/Block Exogeneity Wald Tests as disclosed in Table 8, we have reasonable evidence of Granger causality from country-level governance to GDP for $p$-value $>0.05$, but from GDP to country-level governance the causality is not confirmed ( $p$-value $<0.05)$. 
Table 7. The ordinary least square regression.

\begin{tabular}{|c|c|c|c|c|}
\hline & Coefficient & Std. Error & $\mathrm{t}$-Statistic & Prob. \\
\hline $\mathrm{C}(1)$ & -0.005432 & 0.002144 & -2.533349 & 0.0114 \\
\hline$C(2)$ & -0.540325 & 0.025659 & -21.05759 & 0.0000 \\
\hline$C(3)$ & 1525.184 & 573.7283 & 2.658373 & 0.0079 \\
\hline$C(4)$ & -0.375658 & 0.025093 & -14.97051 & 0.0000 \\
\hline$C(5)$ & 837.9049 & 433.2918 & 1.933812 & 0.0534 \\
\hline$C(6)$ & 67.09493 & 24.60525 & 2.726854 & 0.0065 \\
\hline $\mathrm{C}(7)$ & -0.00000275 & 0.000000204 & -13.46703 & 0.0000 \\
\hline $\mathrm{C}(8)$ & 0.0000027 & 0.00000244 & 1.107617 & 0.2682 \\
\hline$C(9)$ & -0.044157 & 0.054593 & -0.808837 & 0.4188 \\
\hline$C(10)$ & 0.000000954 & 0.00000239 & 0.399423 & 0.6896 \\
\hline$C(11)$ & -0.085219 & 0.041230 & -2.066912 & 0.0389 \\
\hline$C(12)$ & 0.002226 & 0.002341 & 0.950537 & 0.3420 \\
\hline \multicolumn{5}{|c|}{ Determinant residual covariance: 1332.774} \\
\hline \multirow{2}{*}{\multicolumn{5}{|c|}{$\begin{array}{l}\text { Model } 1 \\
\text { Equation: } \mathrm{D}(\mathrm{DGDP})=\mathrm{C}(1) \times\left(\mathrm{DGDP}(-1)+306115.532113 \times \mathrm{DGOV} \_\mathrm{AVG}(-1)-1930.13236825+\mathrm{C}(2) \times\right. \\
\mathrm{D}(\mathrm{DGDP}(-1))+\mathrm{C}(3) \times \mathrm{D}\left(\mathrm{DGOV} \_\mathrm{AVG}(-1)\right)+\mathrm{C}(4) \times \mathrm{D}(\mathrm{DGDP}(-2))+\mathrm{C}(5) \times \mathrm{D}\left(\mathrm{DGOV} \_\mathrm{AVG}(-2)\right)+\mathrm{C}(6)\end{array}$}} \\
\hline & & & & \\
\hline \multicolumn{5}{|l|}{ Observations: 648} \\
\hline R-squared & 0.451411 & Mean dependent var. & & \\
\hline Adjusted R-squared & 0.447139 & S.D. dependent var. & & \\
\hline S.E. of regression & 623.6523 & Sum squared resid. & & \\
\hline Durbin-Watson stat & 1.664150 & & & \\
\hline \multicolumn{5}{|l|}{ Model 2} \\
\hline \multicolumn{5}{|c|}{$\begin{array}{l}\text { Equation: D(DGOV_AVG })=C(7) \times(\text { DGDP }(-1)+306115.532113 \times \text { DGOV_AVG }(-1)-1930.13236825+C(8) \times \\
D(D G D P(-1))+(9) \times D\left(D G O V \_A V G(-1)\right)+C(10) \times D(D G D P(-2))+C(11) \times D\left(D G O V \_A V G(-2)\right)+C(12)\end{array}$} \\
\hline \multicolumn{5}{|l|}{ Observations: 648} \\
\hline R-squared & 0.465056 & Mean dependent var. & & \\
\hline Adjusted R-squared & 0.460889 & S.D. dependent var. & & \\
\hline S.E. of regression & 0.059344 & Sum squared resid. & & \\
\hline Durbin-Watson stat & 1.988858 & & & \\
\hline
\end{tabular}

Sample: 2006-2015. Included observations: 648. Total system (balanced) observations: 1296.

Table 8. Testing for Granger Causality GOV_AVG_-GDP.

\begin{tabular}{|c|c|c|c|}
\hline \multicolumn{4}{|c|}{ Dependent Variable: D(DGDP) } \\
\hline Excluded & Chi-sq & $\mathrm{df}$ & Prob. \\
\hline D(DGOV_AVG) & 7.198005 & 2 & 0.0274 \\
\hline All & 7.198005 & 2 & 0.0274 \\
\hline \multicolumn{4}{|c|}{ Dependent Variable: D(DGOV_AVG) } \\
\hline Excluded & Chi-sq & $\mathrm{df}$ & Prob. \\
\hline D(DGDP) & 1.226922 & 2 & 0.5415 \\
\hline All & 1.226922 & 2 & 0.5415 \\
\hline
\end{tabular}

VEC Granger Causality/Block Exogeneity Wald Tests. Sample: 2006-2015. Included observations: 648.

As one author admits [24], the causal relationship from economic growth to changes in the quality of governance has received less interest in the previous literature, even if there are some reasons to suppose that improvements in economic growth is often followed by the increasing of quality of governance. Increasing the level of economic growth is supposed to generate improvements in the quality of governance, because economic performance can deliver the necessary financial resources to implement expensive reforms required by the complex process of improving the quality of governance $[24,38,39,44]$.

The empirical analysis reported above contributes to the literature by investigating for causal relationship between the quality of country-level governance and economic growth (measured by 
GDP), using country-level data for a large sample of 136 world-wide economies covering 10 years. A benefit of our paper is taking in consideration both directions of causality between country-level governance and economic growth, while most of the previous studies focused only on one direction, mostly from governance to economic development $[9,24]$. One relevant study in this field which investigated both directions of causality between the quality of governance and economic performance is conducted by an author [24], who uses Chinese provincial-level data covering 20 years. The major difference in our empirical analysis is the usage of country-level data.

Our findings show a significant and positive effect of country-level governance on economic growth, but no significant influence of economic growth on the quality of country-level governance, by using a large sample of countries for a period of 10 years (2006-2015). Our results invalidate some of the previous findings obtained by other authors [24]. By using data at the provincial level in China during the post-Mao reform era, this author empirically proves a significant and positive effect of economic growth on quality of governance, but no significant effect of quality of governance on overall GDP growth [24]. However, the same author points out that instead of the positive effect of economic growth found on subsequent quality of governance, still "more attention should be paid to possible reverse causality in cross-country studies of governance and growth" [24] (p. 147). Thus, our study intends to fill this gap in this field of cross-country analysis of governance and growth.

Another major study conducted by the World Bank researchers [9] analyzes the linkage between country-level governance and economic development, using a newly-updated set of worldwide governance indicators covering the period 2000-2001 for a sample of 175 countries. They started from the premise that good governance is not only critical to economic performance but also it is one of the most significant indicators in appreciating whether a country has the capacity to have an effective resource allocation in order to promote growth and reducing poverty. Their conclusion is that economic growth and the quality of governance are strongly positively correlated across countries, proposing an empirical strategy that involves the investigation of this correlation on two directions: (i) a strong positive causal effect from the quality of governance to subsequent economic growth; and (ii) a weak and even negative causal effect running in the inverse direction from economic growth to the quality of governance [9]. The World Bank researchers emphasize the relevancy of the second conclusion, thus, suggesting "the absence of virtuous circles" [9] (p. 1) in which a higher level of economic growth leads to subsequent improvement in the quality of governance.

Following the results of our empirical analysis presented above, we have arrived at the same conclusion, which confirms the views of the World Bank researchers, concluding that there is no significant influence of economic growth on the quality of subsequent quality of country-level governance, while from the opposite direction there is a strong positive causal effect from country-level governance to economic growth.

\subsection{Results of the Granger Non-Causality Tests for ANS—GOV_AVG}

The second bidirectional relationship according to Hypothesis 3 and 4 proposed to be tested in our study refers from ANS to GOV_AGV and vice versa. We summarize the ANS-GOV_AVG model in the following VAR system:

$$
\begin{gathered}
(\text { DANS })_{t}=\alpha_{1}+\sum_{i=1}^{n} \beta_{1, i}(D A N S)_{t-i}+\sum_{i=1}^{n} \gamma_{1, i}\left(D G O V \_A V G\right)_{t-i}+\varepsilon_{1, t} \\
(\text { DGOV_AVG })_{t}=\alpha_{2}+\sum_{i=1}^{n} \beta_{2, i}\left(D G O V \_A V G\right)_{t-i}+\sum_{i=1}^{n} \gamma_{2, i}(D A N S)_{t-i}+\varepsilon_{2, t}
\end{gathered}
$$

where $\varepsilon_{1, t}$ are $\varepsilon_{2, t}$ are independently and normally distributed error terms, $\alpha_{1}, \alpha_{2}$, are constants and $\beta_{1, i}, \beta_{2, i}, \gamma_{1, i}, \gamma_{2, i}$ for $i=1, \ldots ., N$ are coefficients. 
Similar to the variable GDP, the next step in testing Granger non-causality is to see if the time-series are cointegrated. The results of the Pedroni residual cointegration tests are disclosed in the following Table 9 .

Table 9. The Pedroni residual co-integration test.

\begin{tabular}{lllll}
\hline \multicolumn{5}{l}{ Alternative Hypothesis: Common AR Coefficients. (Within-Dimension) } \\
\hline & Statistic & Prob. & Weighted Statistic & Prob. \\
\hline Panel v-Statistic & 1.071893 & 0.1419 & -4.193674 & 1.0000 \\
Panel rho-Statistic & -6.507472 & 0.0000 & -6.027947 & 0.0000 \\
Panel PP-Statistic & -30.57998 & 0.0000 & -25.34308 & 0.0000 \\
Panel ADF-Statistic & -19.27449 & 0.0000 & -17.35816 & 0.0000 \\
\hline Alternative Hypothesis: Individual AR Coefficients (Between-Dimension) \\
\hline \multicolumn{5}{c}{ Prob. } \\
\hline Group rho-Statistic & Statistic & -0.423661 & 0.3359 & \\
Group PP-Statistic & -34.90035 & 0.0000 & \\
Group ADF-Statistic & -18.63660 & 0.0000 & \\
\hline
\end{tabular}

Pedroni Residual Co-integration Test. Series: DANS; DGOV_AVG. Sample: 2006-2015. Included observations: 1360. Cross-sections included: 136. Null Hypothesis: No co-integration. Trend assumption: No deterministic trend. User-specified lag length: 1. Newey-West automatic band width selection and Bartlett kernel.

After analyzing the results from Table 9, because of the $p$-value $<0.05$ for $8 / 11$ tests, we reject the null hypothesis and one can say that the ANS and the GOV_AVG time-series are cointegrated. Because we tested for Granger non-causality and the series are co integrated, we are using the Vector Error Correction Model (VECM) disclosed in Table A2 from Appendix A. The next step is to establish the correct number of lags.

The various information criteria presented in Table 10 suggest that we should have a maximum lag length of 0 for each variable, except LR which indicates 5 lags. Therefore, we develop our analysis on two situations, for 0 lag and for 5 lags. The results of applying the Vector Error Correction Model (VECM) for 0 lag are disclosed in Table A2 from Appendix A. According to the Table A2, R-square (0.613) from column 2 explains the variance $-61 \%$ of the model1, when adjusted net savings on its lags and the lags of GOV_AVG, while R-square (0.202587) from column 1 explains the variance $-20 \%$ of the model 2 when GOV_AVG on its lags and the lags of adjusted net savings. Further, we tested and estimated the coefficients using the OLS (Ordinary Least Square) regression, as it is shown in the following table.

Table 10. Test for selecting the number of lags.

\begin{tabular}{ccccccc}
\hline Lag & LogL & LR & FPE & AIC & SC & HQ \\
\hline 0 & -138.3271 & NA & $0.046093 *$ & $2.598650 *$ & $2.648319 *$ & $2.618789 *$ \\
1 & -134.7398 & 6.975327 & 0.046447 & 2.606292 & 2.755300 & 2.666709 \\
2 & -134.2766 & 0.883457 & 0.049597 & 2.671789 & 2.920135 & 2.772484 \\
3 & -133.2120 & 1.991191 & 0.052379 & 2.726149 & 3.073832 & 2.867122 \\
4 & -132.0013 & 2.219724 & 0.055179 & 2.777801 & 3.224823 & 2.959052 \\
5 & -125.9479 & $10.87355 *$ & 0.053154 & 2.739777 & 3.286137 & 2.961306 \\
6 & -123.9863 & 3.450984 & 0.055250 & 2.777525 & 3.423223 & 3.039332 \\
7 & -122.1099 & 3.231691 & 0.057539 & 2.816849 & 3.561886 & 3.118935 \\
8 & -119.0038 & 5.234364 & 0.058597 & 2.833403 & 3.677778 & 3.175766 \\
\hline
\end{tabular}

VAR Lag Order Selection Criteria. Endogenous variables: DGOV_AVG; DANS. Exogenous variables: C. Sample: 2006-2015. Included observations: 108. * indicates lag order selected by the criterion. LR: sequential modified LR test statistic (each test at 5\% level); FPE: Final prediction error; AIC: Akaike information criterion; SC: Schwarz information criterion; HQ: Hannan-Quinn information criterion. 
One can note from Table 11 that $\mathrm{C}(1)$ for model 1 and $\mathrm{C}(5)$ for model 2 are the error correction terms, when these are negative in coefficient and significant then we can say that there is a long run causality running from independent to dependent. There would be a speed of adjustment towards long-run equilibrium. For model $1, C(1)=-0.014, p$-value $<0.05$, one can conclude that there is a long run causality running from GOV_AVG to ANS, while for model $2, C(5)=-6.408, p$-value $<0.05$ there is a long run causality running from ANS to GOV_AVG.

Table 11. The ordinary least square regression.

\begin{tabular}{ccccc}
\hline & Coefficient & Std. Error & t-Statistic & Prob. \\
\hline C(1) & -0.014048 & 0.006002 & -2.340674 & 0.0194 \\
C(2) & -0.465129 & 0.035272 & -13.18681 & 0.0000 \\
C(3) & 0.002126 & 0.000727 & 2.925411 & 0.0035 \\
C(4) & -0.000125 & 0.002637 & -0.047422 & 0.9622 \\
C(5) & -6.408536 & 0.278589 & -23.00359 & 0.0000 \\
C(6) & 4.515385 & 1.637246 & 2.757914 & 0.0059 \\
C(7) & 0.037691 & 0.033736 & 1.117247 & 0.2641 \\
C(8) & 0.204013 & 0.122415 & 1.666569 & 0.0958 \\
\hline
\end{tabular}

Determinant residual covariance: 0.058942

\begin{tabular}{|c|c|c|c|}
\hline \multicolumn{4}{|c|}{$\begin{array}{l}\text { Equation: D(DGOV_AVG })=\mathrm{C}(1) \times(\text { DGOV_AVG }(-1)+0.198065598161 \times \mathrm{DANS}(-1)+ \\
0.0672362624549)+\mathrm{C}(2) \times \mathrm{D}\left(\mathrm{DGOV} \_\mathrm{AVG}(-1)\right)+\mathrm{C}(3) \times \mathrm{D}(\mathrm{DANS}(-1))+\mathrm{C}(4)\end{array}$} \\
\hline \multicolumn{4}{|l|}{ Observations: 757} \\
\hline R-squared & 0.202587 & Mean dependent var. & -0.000711 \\
\hline Adjusted R-squared & 0.199410 & S.D. dependent var. & 0.081072 \\
\hline S.E. of regression & 0.072540 & Sum squared resid. & 3.962331 \\
\hline Durbin-Watson stat & 2.240524 & & \\
\hline \multirow{2}{*}{\multicolumn{4}{|c|}{$\begin{array}{l}\text { Model } 2 \\
\text { Equation: D }(\text { DANS })=C(5) \times(\text { DGOV_AVG }(-1)+0.198065598161 \times \text { DANS }(-1)+0.0672362624549)+ \\
\text { C }(6) \times \text { D }(\text { DGOV_AVG }(-1))+C(7) \times \text { D }(\text { DANS }(-1))+C(8)\end{array}$}} \\
\hline & & & \\
\hline \multicolumn{4}{|l|}{ Observations: 757} \\
\hline R-squared & 0.613000 & Mean dependent var. & 0.205111 \\
\hline Adjusted R-squared & 0.611458 & S.D. dependent var. & 5.401812 \\
\hline S.E. of regression & 3.367118 & Sum squared resid. & 8537.127 \\
\hline Durbin-Watson stat & 1.785402 & & \\
\hline
\end{tabular}

Sample: 2006-2015. Included observations: 757. Total system (balanced) observations: 1514.

One can note form Table 12 that for $p$-value $<0.05$ we have to accept the null hypothesis that ANS does not granger cause GOV_AVG and also for a $p$-value $<0.05$ we have to accept the null hypothesis that GOV_AVG does not granger cause ANS. Because, the bidirectional Granger causality between country-level governance and adjusted net savings is not confirmed for lag 0 , in the following, we retest the bidirectional causality between ANS and GOV_AVG for 5 lags. In Table A3 from Appendix A, there are disclosed the results of applying Vector Error Correction Estimates for GOV_AVG-ANS for 5 lags. According to these results, R-square (0.563534) from column 2 explains the variance $-56 \%$ of the model 3, when ANS on its lags and the lags of GOV_AVG, while R-square (0.401178) from column 1 explains the variance $-40 \%$ of the model 4 when GOV_AVG on its lags and the lags of ANS. For the model 4, one can note an increase in variance explained, take into account 5 lags. Then, we tested and estimated the coefficients by using the OLS (Ordinary Least Square) regression, as it is shown in Table 13. 
Table 12. Vector error granger causality/block exogeneity Wald tests.

\begin{tabular}{lcll}
\hline \multicolumn{2}{l}{ Dependent Variable: D(DGOV_AVG) } & & \\
\hline Excluded & Chi-s q & $\mathrm{df}$ & Prob. \\
D(DANS) & 8.558032 & 1 & 0.0034 \\
All & 8.558032 & 1 & 0.0034 \\
\hline \multicolumn{1}{l}{ Dependent Variable: D(DANS) } & & \\
\hline Excluded & Chi-s q & $\mathrm{df}$ & Prob. \\
D(DGOV_AVG) & 7.606091 & 1 & 0.0058 \\
All & 7.606091 & 1 & 0.0058 \\
\hline
\end{tabular}

Sample: 2006-2015. Included observations: 757.

Table 13. The ordinary least square regression.

\begin{tabular}{|c|c|c|c|c|}
\hline & Coefficient & Std. Error & t-Statistic & Prob. \\
\hline $\mathrm{C}(1)$ & 0.003936 & 0.011243 & 0.350120 & 0.7264 \\
\hline$C(2)$ & -0.777728 & 0.058683 & -13.25308 & 0.0000 \\
\hline$C(3)$ & 0.000541 & 0.003084 & 0.175557 & 0.8607 \\
\hline$C(4)$ & -0.575139 & 0.077150 & -7.454800 & 0.0000 \\
\hline$C(5)$ & -0.000104 & 0.002740 & -0.037794 & 0.9699 \\
\hline$C(6)$ & -0.299770 & 0.074819 & -4.006591 & 0.0001 \\
\hline$C(7)$ & -0.000672 & 0.002242 & -0.299825 & 0.7644 \\
\hline$C(8)$ & -0.088062 & 0.070042 & -1.257280 & 0.2091 \\
\hline$C(9)$ & -0.001554 & 0.001660 & -0.936255 & 0.3495 \\
\hline$C(10)$ & -0.123034 & 0.058344 & -2.108786 & 0.0354 \\
\hline $\mathrm{C}(11)$ & 0.000121 & 0.000943 & 0.127852 & 0.8983 \\
\hline$C(12)$ & 0.002688 & 0.003887 & 0.691668 & 0.4894 \\
\hline$C(13)$ & -3.284107 & 0.523369 & -6.274932 & 0.0000 \\
\hline$C(14)$ & 1.489157 & 2.731669 & 0.545145 & 0.5858 \\
\hline$C(15)$ & -0.192543 & 0.143570 & -1.341113 & 0.1804 \\
\hline$C(16)$ & 1.526479 & 3.591321 & 0.425047 & 0.6709 \\
\hline$C(17)$ & -0.159111 & 0.127528 & -1.247653 & 0.2126 \\
\hline$C(18)$ & -1.913750 & 3.482811 & -0.549484 & 0.5829 \\
\hline$C(19)$ & -0.247985 & 0.104368 & -2.376059 & 0.0178 \\
\hline$C(20)$ & -1.003416 & 3.260430 & -0.307756 & 0.7584 \\
\hline$C(21)$ & -0.190119 & 0.077251 & -2.461064 & 0.0141 \\
\hline$C(22)$ & 1.222696 & 2.715876 & 0.450203 & 0.6527 \\
\hline$C(23)$ & -0.129255 & 0.043882 & -2.945523 & 0.0033 \\
\hline$C(24)$ & 0.307939 & 0.180935 & 1.701928 & 0.0893 \\
\hline \multicolumn{5}{|c|}{ Determinant residual covariance: 0.037870} \\
\hline \multicolumn{5}{|c|}{ 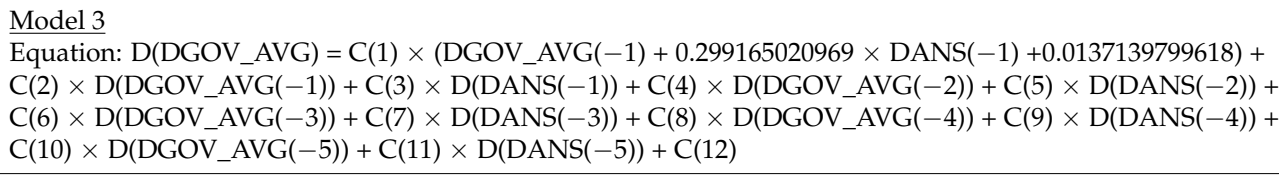 } \\
\hline \multicolumn{5}{|l|}{ Observations: 324} \\
\hline R-squared & 0.401178 & Mean dependent var. & & \\
\hline Adjusted R-squared & 0.380066 & S.D. dependent var. & & \\
\hline S.E. of regression & 0.065899 & Sum squared resid. & & \\
\hline Durbin-Watson stat & 2.403621 & & & \\
\hline \multicolumn{5}{|c|}{$\begin{array}{l}\text { Equation: D(DANS })=\mathrm{C}(13) \times(\text { DGOV_AVG }(-1)+0.299165020969 \times \mathrm{DANS}(-1)+0.0137139799618)+\mathrm{C}(14) \\
\times \mathrm{D}\left(\mathrm{DGOV} \_\mathrm{AVG}(-1)\right)+\mathrm{C}(15) \times \mathrm{D}(\mathrm{DANS}(-1))+\mathrm{C}(16) \times \mathrm{D}\left(\mathrm{DGOV} \_\mathrm{AVG}(-2)\right)+\mathrm{C}(17) \times \mathrm{D}(\mathrm{DANS}(-2))+ \\
\mathrm{C}(18) \times \mathrm{D}\left(\mathrm{DGOV} \_\mathrm{AVG}(-3)\right)+\mathrm{C}(19) \times \mathrm{D}(\mathrm{DANS}(-3))+\mathrm{C}(20) \times \mathrm{D}\left(\mathrm{DGOV} \_\mathrm{AVG}(-4)\right)+\mathrm{C}(21) \times \\
\mathrm{D}(\mathrm{DANS}(-4))+\mathrm{C}(22) \times \mathrm{D}(\mathrm{DGOV} \text { _AVG }(-5))+\mathrm{C}(23) \times \mathrm{D}(\mathrm{DANS}(-5))+\mathrm{C}(24)\end{array}$} \\
\hline \multicolumn{5}{|l|}{ Observations:324 } \\
\hline R-squared & 0.563534 & Mean dependent var. & & \\
\hline Adjusted R-squared & 0.548146 & S.D. dependent var. & & \\
\hline S.E. of regression & 3.067563 & Sum squared resid. & & \\
\hline Durbin-Watson stat & 1.626193 & & & \\
\hline
\end{tabular}

Sample: 2006-2015. Included observations: 324. Total system (balanced) observations: 648 .

One can observe in Table 13 that $C(1)$ is positive and not significant; there is no long run effect of ANS in GOV_AVG. On the other hand, C(13) is negative in coefficient and significant thus one can 
say that there is a long run causality running from GOV_AVG to ANS. There would be a speed of adjustment towards long run equilibrium.

Considering a lag of 5 and also for a $p$-value $>0.05$ we reject the null hypotheses, thus, at first view, this would mean that the country-level governance granger causes adjusted net savings. Thus, for 5 lags, the results disclosed in Table 14 show bidirectional causality between GOV_AVG and ANS. But these findings corroborated with the previous ones, when for lag 0 the bidirectional causality is not confirmed and the fact there is no long run effect of ANS in GOV_AVG, we conclude that for causality relation between country-level governance and adjusted net savings, Granger causality is not truly confirmed, while the results are inconsistent.

Table 14. Vector error granger causality/block exogeneity Wald tests.

\begin{tabular}{cccc}
\hline \multicolumn{5}{c}{ Dependent Variable: } & D(DGOV_AVG) \\
\hline Excluded & Chi-sq & $\mathrm{df}$ & Prob. \\
D(DANS) & 5.502566 & 5 & 0.3577 \\
All & 5.502566 & 5 & 0.3577 \\
\hline \multicolumn{5}{c}{ Dependent Variable: D(DANS) } \\
\hline Excluded & Chi-sq & $\mathrm{df}$ & Prob. \\
D(DGOV_AVG) & 2.564868 & 5 & 0.7667 \\
All & 2.564868 & 5 & 0.7667 \\
\hline Sample: & 2006-2015. Included observations: 324
\end{tabular}

The results of the empirical analysis reported above contributes to the literature by investigating for a causal link between the quality of country-level governance and sustainable development (measured by ANS), by using country-level data for a sample of 136 world-wide countries covering a period of 10 years. We take into consideration both directions of causality between the quality of governance and sustainable development, while previous studies in this field investigated only one direction, usually from the quality of governance to sustainable development [64].

For instance, a relevant study shows a significant and causal positive relationship between good governance and sustainable development measured with the adjusted net saving (ANS) indicator, while the quality of governance is estimated by using an average of six dimensions of governance [64]. This author has used an instrumental variable to establish a one-directional effect of the quality of governance on sustainable development (measured by ANS) to exclude opposite causality [64]. Surprisingly, our findings when testing bidirectional causality between country-level governance and sustainable development (measured by the ANS indicator) does not truly confirm the causality direction from none of the directions. Thus, our results partially invalidate some of the previous results in this field [64]. However, the same author outlines that one of the major problems in estimating the impact of the quality of governance on sustainable development is the question of causality, being perfectly aware that although there seems to be a positive correlation between governance and sustainable development, still "the direction of the causality is not clear" [64] (p. 795). Despite of our results that are not very consistent about the real causality between the quality of governance and sustainable development, our paper intends to contribute to the literature in this field of cross-country analysis of governance and sustainable development, by bringing in the attention of academics the necessity to deeply investigate potential factors that might influence this causal relationship and to provide well-argued answers to the question of causality between the quality of governance and sustainable development, perhaps with the choice of other relevant indicators for sustainable development.

\section{Conclusions}

An adapted version Toda-Yamamoto of the Granger non-causality test [49] was used within this paper to test causality between country-level governance and economic growth, at the one hand, and between country-level governance and a selected indicator of sustainable development (ANS), 
on the other hand, in 136 countries over the period 2006-2015. Our findings show a significant and positive effect of the quality of country-level governance on economic growth, but in the opposite relation there is no significant effect of economic performance on the governance. When we tested the bidirectional Granger causality between governance and the adjusted net savings, as a selected indicator of sustainable development, the bidirectional causality was not confirmed. Through this paper, we intend to emphasize the risk of misinterpreting the relationship between country-level governance and the selected indicators of economic growth and sustainable development, suggesting the opportunity to further investigate bilateral causality between good governance and sustainable development, perhaps with the selection of other relevant indicators such as the Genuine Progress Indicator (GPI) or the Human Development Index (HDI).

Because by following our empirical analysis, the bidirectional Granger causality between governance and sustainable development was only partially confirmed, we conclude that our findings only partially support the hypotheses issued above. Also, the authors admit that additional investigation is required to further empirically analyze the reverse causality between country-level governance and others relevant indicators for sustainable development.

No doubt, as some author admits [39], the methodological choices about how to empirically investigate the relationship between country-level governance, economic growth and sustainable development have a significant impact on findings. Thus, the same author points out that for large- $\mathrm{N}$ studies consistent correlations between good governance and development tend to be founded. On the other hand, for small-N studies, the same author admits that weak correlations between governance and development tend to be argued. While the empirical analyses based on large-N studies contributed to the increasing of the difficult lists of "things that must be done" [39] (p. 559), other researchers investigated the relationship between governance and economic development by using the experience of countries with imposing records of economic growth and poverty reduction, suggesting that both economic growth and sustainable development can be positively stimulated by a certain number of institutional and policy changes [39]. In this vein, our paper may be considered as an invitation to future academic debates where arguments for the best methodological choices and selection of most adequate indicators can be discussed.

The concept of sustainable development assumes a balance between all three dimensions: economic growth, environmental sustainability and social development. Since past patterns of economic development have generated the degradation of the global environment future, economic growth must be achieved in an environmentally friendly way. In this context, after many years when economic growth was considered a prime goal of government policy, its objective and its main measure, the Gross Domestic Product, have been questioned. Even on short term economic growth has many benefits, on long term we need to take into consideration the negative impact it has on the planet, so a balance between economic growth and sustainability needs to be found, economies need to grow but simultaneously must to be capable to sustain the planet. Priorities need to be changed; new plans and strategies need to be adopted in order to ensure economic development that satisfy people needs without compromising resources availability and to be able to sustain the environment for future generations. The GDP as one of the main indicator of economic growth is not a suitable indicator anymore, capable to reflect a sustainable development path of an economy. This must be replaced by adjusted net savings (ANS) that incorporate information about the state of the environment and natural resources. If the traditional national accounting measures failed to reflect the importance of environmental quality and natural capital this new macro level index of sustainable development accomplishes this task. A positive value for this index indicates that a specific economy follows a sustainable path. This index is more valuable in resource-rich countries, usually underdeveloped or developing countries, where resource exploitation generates large financial revenues on short term, so they consider that the actual situation will create a prosperous future. Taking into consideration the depreciation of fixed capital, the natural resources depletion and pollution damages, the lack of investment in human capital, this index will reflect better these countries' situation, 
so that decision-makers have access to perfect information in order to create an adequate strategy of resources' reinvestment. Countries need to have strong institutions and national authorities that are able to regulate strong enough resource exploitation, pollution issues, and education expenditures. If adequate measures are adopted, countries can prosper; otherwise exhaustion of natural resources reserves will return countries to their original level of development. Proactive efforts to set goals in order to prevent resource depletion, reducing of pollution and human capital development, must be adopted at national level. Planning, developing and implementing strategies, programs, and policies designed specifically after establishing the adjusted net savings (ANS) indicator can help countries to achieve a future sustainable development. Different categories of countries need to adopt different forms of good governance in order to achieve sustainable development. Less developed countries are facing more with corruption practices in their actions to attract more potential investors, which can stimulate economic growth, therefore governance reforms will be preponderantly directed towards these corruption practices based on the fact that usually investors are mostly trying to exploit natural resources. Why this is necessary: because on short term the countries' financial revenues will increase but on long term the resources' depletion will increase the level of poverty. Developing countries, known as having a better internal organization, have more available tools to allocate more resources toward the education system.

Probably a challenge of the future will be to look for potential solutions that might have a contribution to the overcoming of the obstacles that might negatively affect the process of successful implementation of the Sustainable Development Goals within the countries from all over the world, particularly if we have in our mind the significant conclusions of the Brundtland Report according to which "sustainable development must rest on political will" [22] (p. 17), while in order to achieve our long-term common goals growing political and governmental efforts will have to address our common future. Undoubtedly, for ensuring the human progress and the adequate social welfare of people from all over the world, it is absolutely imperative to look for safe, environmental friendly and economically viable solutions in the near future. And for that it is absolutely imperative to develop new dimensions of political actions corroborated with institutional cooperation, so that to ensure the adequate premises for a long-term sustainable development.

Author Contributions: The authors individual contributions are the following ones: Cristina Boţa-Avram and Paula-Ramona Răchişan conceived and designed the statistical data base; Adrian Groşanu and Marius Dan Gavriletea performed the data base; Paula-Ramona Răchişan and Cristina Boţa-Avram analyzed the data; Adrian Groşanu and Marius Dan Gavriletea contributed with analysis tools; Cristina Boţa-Avram and Paula-Ramona Răchişan wrote the paper.

Conflicts of Interest: The authors declare no conflict of interest. The founding sponsors had no role in the design of the study; in the collection, analyses, or interpretation of data; in the writing of the manuscript, and in the decision to publish the results.

\section{Appendix A}

Table A1. Vector error correction estimates for GOV-GDP.

\begin{tabular}{ccc}
\hline Cointegrating Equation: & \multicolumn{2}{c}{ CointEq1 } \\
\hline DGDP $(-1)$ & 1.000000 & \\
DGOV_AVG $(-1)$ & 306115.5 & \\
C & $(22837.9)[13.4038]$ & D(DGOV_AVG) \\
Error Correction: & -1930.132 & -0.00000275 \\
CointEq1 & D(DGDP) & $(0.0000002)[-13.4670]$ \\
D(DGDP $(-1))$ & -0.005432 & 0.0000027 \\
& $(0.00214)[-2.53335]$ & $0.0000024)[1.10762]$ \\
D(DGDP $(-2))$ & -0.540325 & 0.000000954 \\
& $(0.02566)[-21.0576]$ & $(0.0000024)[0.39942]$ \\
D(DGOV_AVG $(-1))$ & -0.375658 & -0.044157 \\
\hline
\end{tabular}


Table A1. Cont.

\begin{tabular}{ccc}
\hline Cointegrating Equation: & \multicolumn{2}{c}{ CointEq1 } \\
\hline & $(573.728)[2.65837]$ & $(0.05459)[-0.80884]$ \\
D(DGOV_AVG $(-2))$ & 837.9049 & -0.085219 \\
C & $(433.292)[1.93381]$ & $(0.04123)[-2.06691]$ \\
R-squared & 67.09493 & 0.002226 \\
Adj. R-squared & $(24.6053)[2.72685]$ & $(0.00234)[0.95054]$ \\
Sum square residuals & 0.451411 & 0.465056 \\
S.E. equation & 0.447139 & 0.460889 \\
F-statistic & 2.5000000 & 2.260930 \\
Log likelihood & 623.6523 & 0.059344 \\
Akaike AIC & 105.6551 & 111.6249 \\
Schwarz SC & -5086.722 & 913.7569 \\
Mean dependent & 15.71828 & -2.801719 \\
S.D. dependent & 15.75970 & -2.760294 \\
Determinant residual covariance (dof adj.) & 0.002063 \\
Determinant residual covariance & 0.080823 \\
Log likelihood & 1357.802 \\
Akaike information criterion & 1332.774 \\
Schwarz criterion & -4170.130 \\
Sch & 104.7035 & 12.91398 \\
\end{tabular}

Sample (adjusted): 2006-2015. Included observations: 648 after adjustments. Standard errors in ( )\& t-statistics in [].

Table A2. Vector error correction estimates for ANS-GOV_AVG for 0 lag.

\begin{tabular}{ccc}
\hline R-squared & 0.202587 & 0.613000 \\
\hline Adj.R-squared & 0.199410 & 0.611458 \\
Sumsq.resids & 3.962331 & 8537.127 \\
S.E.equation & 0.072540 & 3.367118 \\
F-statistic & 63.76800 & 397.5787 \\
Loglikelihood & 913.9464 & -1991.173 \\
AkaikeAIC & -2.404086 & 5.271262 \\
SchwarzSC & -2.379624 & 5.295723 \\
Meandependent & -0.000711 & 0.205111 \\
S.D. dependent & 0.081072 & 5.401812 \\
Determinant residual covariance (dof adj.) & 0.059570 \\
Determinant residcovariance & 0.058942 \\
Log likelihood & -1076.666 \\
\multicolumn{2}{c}{ Akaike information criterion } & 2.870981 \\
Schwarz criterion & 2.932135 \\
\hline
\end{tabular}

Sample (adjusted): 2006-2015. Included observations: 648 after adjustments. Standard errors in ( ) \& t-statistics in [ ].

Table A3. Vector error correction estimates for ANS-GOV_AVG for 5 lags.

\begin{tabular}{ccc}
\hline R-squared & 0.401178 & 0.563534 \\
\hline Adj. R-squared & 0.380066 & 0.548146 \\
Sum sq.resids & 1.354900 & 2935.902 \\
S.E. equation & 0.065899 & 3.067563 \\
F-statistic & 19.00212 & 36.62110 \\
Log likelihood & 427.5404 & -816.7884 \\
Akaike AIC & -2.565064 & 5.115978 \\
Schwarz SC & -2.425037 & 5.256005 \\
Meandependent & -0.001648 & 0.177100 \\
S.D. dependent & 0.083696 & 4.563460 \\
Determinant residual covariance (dof adj.) & 0.040840 \\
Determinant residual covariance & 0.037870 \\
Log likelihood & -389.1517 \\
\multicolumn{2}{c}{ Akaike information criterion } & 2.562665 \\
Schwarz criterion & 2.866058 \\
\hline
\end{tabular}

Sample (adjusted): 2006-2015. Included observations: 648 after adjustments. Standard errors in ( ) \& t-statistics in []. 


\section{References}

1. Stojanović, I.; Ateljević, J.; Stević, R.S. Good Governance as a Tool of Sustainable Development. Eur.J. Sustain. Dev. 2016, 5, 558-573. [CrossRef]

2. Groşanu, A.; Boţa-Avram, C.; Răchişan, P.R.; Vesselinov, R.; Tiron-Tudor, A. The influence of country-level governance on business environment and entrepreneurship: A global perspective. Amfiteatru Econ. J. 2015, 17, 60-75.

3. Çule, M.; Fulton, M.E. Corporate governance and subjective well-being. Appl. Econ. Lett. 2013, 20, 364-367. [CrossRef]

4. Demirguc-Kunt, A.; Love, I.; Maksimovic, V. Business Environment and the incorporation decision. J. Bank. Financ. 2006, 30, 2967-2993. [CrossRef]

5. Jalilian, H.; Kirkpatrick, C.; Parker, D. The Impact of regulation on economic growth in developing countries: A cross-country analysis. World Dev. 2006, 35, 87-103. [CrossRef]

6. Olson, M.; Sarna, N.; Swamy, A.V. Governance and Growth: A Simple Hypothesis Explaining Cross-Country Differences in Productivity; Mimeo: Centre of Institutional Reform and Informal Sector (IRIS); University of Maryland: College Park, MD, USA, 1998.

7. Kaufmann, D.; Kraay, A.; Mastruzzi, M. Governance Matters IV: Governance Indicators for 1996-2004; World Bank: Washington, DC, USA, 2005; Available online: http:/ / citeseerx.ist.psu.edu/viewdoc/download?doi= 10.1.1.559.623\&rep=rep1\&type=pdf (accessed on 10 August 2016).

8. Brinkerhoff, D.W.; Goldsmith, A.A. Institutional Dualism and International Development: A Revisionist Interpretation of Good Governance. Adm. Soc. 2005, 37, 199-224. [CrossRef]

9. Kaufmann, D.; Kraay, A. Growth without Governance; Mimeo; The World Bank: Washington, DC, USA, 2002.

10. Ngobo, P.V.; Fouda, M. Is good governance good for business? A cross-national analysis of firms in African countries. J. World Bus. 2012, 47, 435-449. [CrossRef]

11. World Bank. Managing Development: The Governance Dimension; A Discussion Paper; The World Bank: Washington, DC, USA, 1991; Available online: http://documents.worldbank.org/curated/en/ 884111468134710535/pdf/34899.pdf (accessed on 25 October 2017).

12. Bundschuh-Rieseneder, F. Good governance: Characteristics, methods and the Austrian examples. Transylv. Rev. Adm. Sci. 2008, 4, 26-52.

13. World Bank. Governance and Economy: A Review; The World Bank: Washington, DC, USA, 1991; Available online: http:/ / www-wds.worldbank.org/external/default/WDSContentServer/WDSP/IB/1991/12/01/ 000009265_3961002050636/Rendered/PDF/multi0page.pdf (accessed on 10 October 2017).

14. Kaufmann, D.; Kraay, A.; Zoido-Lobaton, P. Aggregating Governance Indicators; World Bank Policy, Research Working Paper No. 2195; The World Bank: Washington, DC, USA, 1999.

15. Boivard, T.; Löffler, E. Evaluating the quality of public governance: Indicators, models and methodologies. Int. Rev. Adm. Sci. 2003, 69, 313-328. [CrossRef]

16. Hood, C.; Beeston, C.; Dixon, R. Rating the rankings: Assessing international rankings of public service performance. Int. Public Manag. J. 2007, 11, 298-328. [CrossRef]

17. Van de Walle, S. The state of the world's bureaucracies. J. Comp. Policy Anal. Res. Pract. 2006, 8, 437-448. [CrossRef]

18. Kaufmann, D.; Kraay, A.; Zoido-Lobaton, P. Governance Matters; World Bank Policy, Research Working Paper No. 2196; The World Bank: Washington, DC, USA, 1999.

19. Andrews, M. The Good Governance Agenda: Beyond Indicators without Theory. Oxf. Dev. Stud. 2008, 36, 379-407. [CrossRef]

20. Wang, G.G.; Korte, R.F.; Sun, J.Y. Development Economics: A Foundation for HRD Policy Studies in Developing Countries. Adv. Dev. Hum. Resour. 2008, 10, 848-862. [CrossRef]

21. Leichtová, M.; Piknerová, L.; Ponízilová, M. Limits of Human Development in Weak States: A Conceptual Evaluation. Int. Stud. 2007, 49, 1-22. [CrossRef]

22. Banik, N.; Yoonus, C.A. Trade as an Answer to Sustainable Economic Growth-The ECOWAS Story. Glob. Bus. Rev. 2012, 13, 311-326. [CrossRef]

23. Soubbotina, T. Beyond Economic Growth: An Introduction to Sustainable Development; The World Bank: Washington, DC, USA, 2004.

24. Wilson, R. Does Governance cause Growth? Evidence from China. World Dev. 2016, 79, 138-151. [CrossRef] 
25. Hall, R.E.; Jones, C.I. Why do some countries produce so much more output per worker than others? Q. J. Econ. 1999, 114, 83-116. [CrossRef]

26. Sharma, S.K. Governance for realising a sustainable society. Soc. Chang. 2001, 31, 165-173. [CrossRef]

27. Cingolani, L.; Thomsson, K.; de Crombrugghe, D. Minding weber more than ever? The impacts of state capacity and bureaucratic autonomy on development goals. World Dev. 2015, 72, 191-207. [CrossRef]

28. Mauro, P. The Persistence of Corruption and Slow Economic Growth. IMF Staff Pap. 2004, 51, 1-23. [CrossRef]

29. Sharma, S.D. Democracy, Good Governance and Economic Development. Taiwan J. Democr. 2007, 3, $29-62$.

30. Rodrik, D. Thinking about Governance. In Governance, Growth and Development Decision-Making; North, D., Acemoglu, D., Fukuyama, F., Rodrik, D., Eds.; The World Bank: Washington, DC, USA, 2008.

31. Khan, M.H. Governance, Economic Growth and Development Since the 1960s; UN DESA Working Paper No. 54; DESA: New York, NY, USA, 2007.

32. Pezzey, J. Economic Analysis of Sustainable Growth and Development; World Bank, Environmental Economic Series; Working Paper No. 15; The World Bank: Washington, DC, USA, 1989.

33. Hamilton, H. Genuine Saving as a Sustainability Indicator; World Bank, Environmental Economic Series; Working Paper No. 77; The World Bank: Washington, DC, USA, 2000.

34. United Nations. Report of the World Commission on Environment and Development: Our Common Future; The Brundtland Report; The World Commission on Environment and Development: Olso, Norway, 1987; Available online: http:/ / www.un-documents.net/our-common-future.pdf (accessed on 6 November 2017).

35. Everett, G.; Wilks, A. The World Bank's Genuine Savings Indicator: A Useful Measure of Sustainability? Bretton Woods Project. Working to Reform the World Bank and IMF. 1999. Available online: http:/ /www. brettonwoodsproject.org/topic/environment/gensavings.pdf (accessed on 7 February 2018).

36. Schepelmann, P.; Goossens, P.Y.; Makipaa, A. Towards Sustainable Development Alternatives to GDP for Measuring Progress; Wuppertal Institute for Climate, Environment and Energy: Wuppertal, Germany, 2010; ISBN 978-3-929944-81-5.

37. Pearce, D.W.; Atkinson, G. Capital Theory and the Measurement of Sustainable Development: An Indicator of Weak Sustainability. Ecol. Econ. 1993, 8, 103-108. [CrossRef]

38. Grindle, M.S. Good Enough Governance: Poverty Reduction and Reform in Developing Countries. Governance 2004, 17, 525-548. [CrossRef]

39. Grindle, M.S. Good enough governance revisited. Dev. Policy Rev. 2007, 25, 553-574. [CrossRef]

40. Grindle, M.S. Good Governance, R.I.P: A critique and an Alternative. Governance 2016, 30, 17-22. [CrossRef]

41. Filho, W.L.; Platje, J.; Gerstlberger, W.; Ciegis, R.; Kaaria, J.; Klavins, M.; Kliucininkas, L. The role of governance in realising the transition towards sustainable societies. J. Clean. Prod. 2016, 113. [CrossRef]

42. Tabellini, G. Culture and Institutions: Economic development in the regions of Europe. J. Eur. Econ. Assoc. 2010, 8, 677-716. [CrossRef]

43. Shepherd, A. Governance, Good Government and Poverty Reduction. Int. Rev. Adm. Sci. 2000, 66, $269-284$. [CrossRef]

44. Rodrik, D.; Subramanian, A.; Trebbi, F. Institutions rule: The primacy of institutions over geography and integration in economic development. J. Econ. Growth 2004, 9, 131-165. [CrossRef]

45. Roy, K.C.; Tisdell, C.A. Good governance in sustainable development: The impact of institutions. Int. J. Soc. Econ. 1998, 25, 1310-1325. [CrossRef]

46. Van Zeijl-Rozema, A.; Cörvers, R.; Kemp, R.; Martens, P. Governance for sustainable development: A framework. Sustain. Dev. 2008, 16, 410-421. [CrossRef]

47. Kemp, R.; Parto, S.; Gibson, R.B. Governance for sustainable development: Moving from theory to practice. Int. J. Sustain. Dev. 2005, 8, 12-30. [CrossRef]

48. Granger, C.W. Investigating causal relations by econometric models and cross-spectral methods. Econometrica 1969, 37, 424-438. [CrossRef]

49. Toda, I.; Yamamoto, T. Statistical inference in vector autoregressions with possibly integrated processes. J. Econom. 1995, 66, 225-250. [CrossRef]

50. Amiri, A.; Venteloub, B. Granger causality between total expenditure on health and GDP in OECD: Evidence from the Toda-Yamomoto approach. Econ. Lett. 2012, 116, 541-544. [CrossRef]

51. Wolde-Rufael, Y. Energy demand and economic growth: The African experience. J. Policy Model. 2005, 27, 891-903. [CrossRef]

52. Maziarz, M. A review of the granger-causality fallacy. J. Philos. Econ. 2015, 8, 86. 
53. Hoover, K.D. Causality in Economics and Econometrics. In The New Palgrave Dictionary of Economics; Chapter 1; Palgrave Macmillan: Basingstoke, UK, 2008; pp. 1-13.

54. World Bank. World Development Indicators; The World Bank: Washington, DC, USA, 2016; Available online: https:/ / openknowledge.worldbank.org/bitstream/handle/10986/23969/9781464806834.pdf (accessed on 1 October 2017).

55. World Bank. Worldwide Governance Indicators (WGI) Project 1996-2011. 2012. Available online: http: / /info.worldbank.org/governance/wgi/index.asp (accessed on 17 August 2016).

56. Levin, A.; Lin, C.-F.; Chu, C.-S.J. Unit root tests in panel data: Asymptotic and finite-sample properties. J. Econom. 2002, 108, 1-24. [CrossRef]

57. Im, K.S.; Pesaran, M.H.; Shin, Y. Testing for unit roots in heterogeneous panels. J. Econom. 2003, 115, 53-74. [CrossRef]

58. Dickey, D.; Fuller, W. Distribution of the estimators for autoregressive time series with a unit root. J. Am. Stat. Assoc. 1979, 74, 427-431. [CrossRef]

59. Wooldridge, J.M. Introductory Econometrics: A Modern Approach; South-Western College Publishing: Mason, OH, USA, 2000.

60. Iqbal, J.; Uddin, M.N. Forecasting accuracy of error correction models: International evidence for monetary aggregate M2. J. Int. Glob. Econ. Stud. 2013, 6, 14-32.

61. Pedroni, P. Critical Values for Cointegration Tests in Heterogeneous Panels with Multiple Regressors. Oxf. Bull. Econ. Stat. 1999, 61, 653-670. [CrossRef]

62. Pedroni, P. Panel Cointegration: Asymptotic and finite sample properties of pooled time series tests with an application to the PPP Hypothesis. Econ. Theory 2004, 20, 597-625. [CrossRef]

63. Green, R.K. Follow the leader: How changes in residential and non-residential investment predict changes in GDP. Real Estate Econ. 1997, 25, 253-270. [CrossRef]

64. Stoever, J. On comprehensive wealth, institutional quality and sustainable development-quantifying the effect of institutional quality on sustainability. J. Econ. Behav. Organ. 2012, 81, 794-801. [CrossRef]

(C) 2018 by the authors. Licensee MDPI, Basel, Switzerland. This article is an open access article distributed under the terms and conditions of the Creative Commons Attribution (CC BY) license (http:/ / creativecommons.org/licenses/by/4.0/). 